\title{
Aire and Foxp3 Expression in a Particular Microenvironment for T Cell Differentiation
}

\author{
Isabelle Hansenne ${ }^{a}$ Céline Louis $^{a}$ Henri Martens ${ }^{a}$ Gauthier Dorban ${ }^{b}$ \\ Chantal Charlet-Renard $^{\mathrm{a}}$ Pärt Peterson ${ }^{\mathrm{c}}$ Vincent Geenen ${ }^{\mathrm{a}}$ \\ ${ }^{a}$ Center of Immunology, Institute of Pathology, and b Laboratory of Histology, University of Liege, \\ Liege-Sart Tilman, Belgium; ' Molecular Pathology, University of Tartu, Tartu, Estonia
}

\section{Key Words}

Thymic nurse cells $\cdot$ Aire $\cdot$ Foxp3 $\cdot$ Regulatory T cells

\begin{abstract}
Objective: The thymus is the primary lymphoid organ responsible for T cell development and the establishment of central self-tolerance. Among thymic epithelial cells, thymic nurse cells (TNC) interact closely with immature thymocytes and constitute a special microenvironment for $\mathrm{T}$ cell differentiation and selection. In addition, TNC express neuroendocrine self-antigens such as oxytocin and insulin-like growth factor-2, whose intrathymic transcription is regulated by the autoimmune regulator gene/protein (Aire). Both effector and natural regulatory $T$ cell (nTreg) lineages develop in the thymus, but the mechanisms leading to nTreg selection in the thymus are still unclear. Foxp3 is the most specific nTreg marker that is required for nTreg functional activity, but not for engagement into the Treg lineage. Aire has been suggested to be a potential factor implicated in this role. The objective of this study was to characterize Aire and Foxp3 expression in TNC/thymocyte complexes. Methods: Aire and Foxp 3 expression was investigated by RT-qPCR in TNC/thymocyte complexes isolated by enzymatic digestion and sedimentation. Aire and Foxp3 proteins were located by confocal microscopy and specific immunocytochemistry. Results: Both Aire and Foxp3 transcripts were
\end{abstract}

detected in TNC/thymocyte complexes. Foxp3 was detected in the nucleus of thymocytes internalized into TNC. Aire was located mainly in TNC cytoplasm and, although to a lower degree, in the nucleus of some TNC-associated thymocytes. Conclusions: Aire and Foxp3 are present in the particular TNC microenvironment which has previously been shown to support thymic selection. The differential localization of these two markers suggests a role for TNC in nTreg development.

Copyright $\odot 2008$ S. Karger AG, Basel

\section{Introduction}

The thymus is the primary lymphoid organ responsible for $\mathrm{T}$ cell development and central self-tolerance. In addition to effector $\mathrm{T}$ cell development, the thymus shapes the repertoire of naturally occurring regulatory $\mathrm{T}$ cells (Treg), also called natural Treg (nTreg), which play a critical role in control of the immune responses $[1,2]$. For induction of $\mathrm{T}$ cell central self-tolerance, thymic epithelial cells (TEC), and more particularly medullary TEC, express a series of tissue-restricted antigens such as neuroendocrine antigens $[3,4]$. Most of the neuroendocrine families are expressed by TEC, notably the insulin family, represented mainly by insulin-like growth factor2 (IGF-2), then IGF-1 and insulin, and the neurohypo-

\section{KARGER}

Fax +4161306 1234 E-Mail karger@karger.ch www.karger.com
(C) 2008 S. Karger AG, Basel 1021-7401/09/0161-0035\$26.00/0

Accessible online at:

www.karger.com/nim
Vincent Geenen

University of Liege, Center of Immunology

Institute of Pathology CHU-B23

BE-4000 Liege-Sart Tilman (Belgium)

Tel. +32 4366 2350, Fax +32 4366 9859, E-Mail vgeenen@ulg.ac.be 
physial family, represented by oxytocin (OT) as the dominant peptide, as well as vasopressin [5-9]. The product of the autoimmune regulator gene (Aire) is a transcription factor involved in controlling the expression of many tissue-restricted antigens by medullary TEC [10]. Airedeficient mice develop autoantibodies and lymphocyte infiltrates in several organs, leading to a spectrum of autoimmune diseases [11, 12]. Several Aire mutations are also described in a rare recessive congenital disease, the autoimmune polyendocrinopathy candidiasis and ectodermal dystrophy syndrome [13]. Aire deletion in mice is associated with reduced expression of many (but not all) self-antigens in the thymus. Among the Aire-dependent genes, the OT, IGF-2 and insulin genes are strongly repressed following the deletion of the gene $[11,14]$.

A particular microenvironment of the thymus is formed by 2 cell types, thymic nurse cells (TNC), a TEC subtype, and immature thymocytes [for a review, see 15, 16]. These complexes were first described in 1980 by Wekerle et al. [17] and are observed both after isolation and in thymic sections $[18,19]$. In situ, these TNC/thymocyte complexes have mainly been described in the outer cortex, and TNC-associated thymocytes are internalized in vacuoles of TNC $[20,21]$. The number of thymocytes engulfed in TNC varies from 2 to 200 and determines the size of the complex. It has been reported that TNC can support T cell development and selection [16]. Neuroendocrine self-antigens such as OT and IGF-2 are expressed by TNC $[7,22]$, but, at present, nothing is known about the regulation of self-antigen expression in TNC or about Aire expression in TNC/thymocyte complexes.

As mentioned above, the thymus is also responsible for nTreg generation. The mechanisms leading to the differentiation and selection of nTreg in the thymus are still largely unclear. The transcription factor Foxp3 is required for the suppressive activity of nTreg, but is not necessary for engagement into the nTreg lineage $[23,24]$. This strongly suggests the intervention of other factors, and Aire has recently been suggested to be involved in this process [25].

The objective of this study was to investigate whether Aire and Foxp3 are expressed in TNC/thymocyte complexes isolated from murine thymi. We show here that Aire is mainly expressed by TNC, while Foxp3 is located in the nucleus of thymocytes engulfed in TNC. These observations support the notion of a link between these transcription factors, and suggest that TNC may also be involved in nTreg development.

\section{Materials and Methods}

\section{Animals}

$\mathrm{Balb} / \mathrm{c}$ mice were provided by the Animal Department of Liege University. They were kept under conventional conditions with free access to food and water. Female mice were 5 weeks old at the time of the experiments, which were performed with the approval of the local ethics committee.

\section{Isolation of TNC/Thymocyte Complexes}

TNC were isolated from Balb/c thymus according to the methods previously described $[17,26]$. The first step was thymic dissociation by enzymatic digestions, and the second step was TNC isolation by sedimentation. For each experiment, 20 thymi from $\mathrm{Balb} / \mathrm{c}$ mice were dissected, placed in sterile cold Dulbecco's phosphate-buffered saline (DPBS; Lonza) supplemented with 5\% FCS (Invitrogen) and sliced into small pieces. Thymus fragments were shaken for $5 \mathrm{~min}$ in $50 \mathrm{ml}$ of sterile cold DPBS supplemented with 5\% FCS. The supernatant containing thymocytes was removed, and fragments were submitted to 5 successive enzymatic digestions. The first 2 digestions were performed with 25 $\mathrm{ml}$ of dispase $(1.2 \mathrm{U} / \mathrm{ml}$; Roche Diagnostics)/DNase $(0.02 \mathrm{mg} / \mathrm{ml}$; Roche Diagnostics) solution for $20 \mathrm{~min}$ under agitation. The next 3 digestions were performed with $25 \mathrm{ml}$ of collagenase $(40 \mathrm{U} / \mathrm{ml}$; Sigma-Aldrich)/DNase $(0.02 \mathrm{mg} / \mathrm{ml})$ solution for $20 \mathrm{~min}$ under agitation. The 'starting fraction', composed of a pool of 5 digestion supernatants in RPMI-1640 (Lonza) supplemented with streptomycin $(100 \mu \mathrm{g} / \mathrm{ml}$; Lonza), penicillin (100 U/ml; Lonza) and L-glutamine ( $2 \mathrm{mM}$; Lonza), was used to isolate TNC by sedimentation. Four runs of sedimentation at $1 \mathrm{~g}$ were performed. The 'starting fraction' was put on $10 \mathrm{ml}$ of FCS (Invitrogen) for $20 \mathrm{~min}$ (step 1). The supernatant was removed and the pellet was used for the following sedimentations (step 2: $10 \mathrm{ml}$ of FCS for 15 min; step 3: $10 \mathrm{ml}$ of FCS for $15 \mathrm{~min}$; step 4: $5 \mathrm{ml}$ of FCS for 15 min). An enriched fraction of TNC was obtained, and the number of cells was estimated by the trypan blue exclusion test (Lonza).

Isolation of Thymocytes, CD4 + T Cells and TEC

Thymocytes and splenocytes from Balb/c mice were isolated by mechanical disruption, erythrocyte lysis (Hybrid-Max ${ }^{\circledR}$, Sigma-Aldrich) and filtration through a $70-\mu \mathrm{m}$ cell strainer (BD Biosciences). CD4+ cells from splenocytes were isolated using MACS technology [CD4 (L3T4) Microbeads and an LS column, Miltenyi Biotec] according to the manufacturer's instructions. TEC were isolated from $\mathrm{Balb} / \mathrm{c}$ thymus by successive enzymatic digestions. Thymi were cut into small pieces, suspended in $5 \mathrm{ml}$ of DPBS per thymus and stirred for $30 \mathrm{~min}$ at $4^{\circ} \mathrm{C}$. Supernatant was removed, and 3 enzymatic digestions were performed with Hanks' balanced salt solution ( $4 \mathrm{ml} /$ thymus, $2 \mathrm{ml} /$ thymus and $1 \mathrm{ml} /$ thymus, respectively; Lonza, Belgium) supplemented with collagenase D (1 mg/ $\mathrm{ml}$; Sigma-Aldrich) and DNase I (10 $\mu \mathrm{g} / \mathrm{ml}$; Roche Diagnostics) for 12,12 and $5 \mathrm{~min}$, respectively, at $37^{\circ} \mathrm{C}$. The last supernatant was treated with trypsin (0.25\%; Lonza) $/ 0.02 \%$ EDTA for $10 \mathrm{~min}$ at $37^{\circ} \mathrm{C}$. The reaction was stopped with Iscove's modified Dulbecco's medium (Lonza) containing 10\% FCS (Invitrogen). The number of cells was estimated by the trypan blue exclusion test. Fresh TEC were cultured for 1 week in Dulbecco's modified Eagle's Medium (Lonza) supplemented with penicillin $(100 \mathrm{U} / \mathrm{ml})$, streptomycin $(100 \mu \mathrm{g} / \mathrm{ml})$, L-glutamine $(2 \mathrm{mM})$, sodium pyruvate 
Table 1. Synthetic primers selected for qRT-PCR and sequencing

\begin{tabular}{llllrr}
\hline Genes & Strand & Primer sequence & $\begin{array}{l}\text { Annealing } \\
\text { temperature, }{ }^{\circ} \mathrm{C}\end{array}$ & $\begin{array}{l}\text { Amplicon } \\
\text { bp }\end{array}$ & $\begin{array}{c}\text { Primer concen- } \\
\text { tration, nM }\end{array}$ \\
\hline Foxp3 & $\begin{array}{l}\text { sense } \\
\text { antisense }\end{array}$ & $\begin{array}{l}\text { TTC-TCA-CAA-CCA-GGC-CAC-TTG } \\
\text { CCC-AGG-AAA-GAC-AGC-AAC-CTT }\end{array}$ & 63 & 88 & 500 \\
\hline Aire & $\begin{array}{l}\text { sense } \\
\text { antisense }\end{array}$ & $\begin{array}{l}\text { ACC-ATG-GCA-GCT-TCT-GTC-CAG } \\
\text { GCA-GCA-GGA-GCA-TCT-CCA-GAG }\end{array}$ & 68 & 456 & 300 \\
\hline$\beta$-Actin & $\begin{array}{l}\text { sense } \\
\text { antisense }\end{array}$ & $\begin{array}{l}\text { AGA-GGG-AAA-TCG-TGC-GTG-AC } \\
\text { CAA-TAG-TGA-TGA-CCT-GGC-CGT }\end{array}$ & 60 & 138 & 300 \\
\hline
\end{tabular}

(1 mM; Lonza), Eagle's minimum essential medium nonessential acid (1\%; Lonza), HEPES (10 mM; Lonza), 2-mercaptoethanol (50 $\mu \mathrm{M}$; Invitrogen) and 10\% heat-inactivated FCS (Invitrogen). Approximately $95 \%$ of cultured cells were identified as TEC [27].

\section{$R T-q P C R$}

Total RNA was extracted using an RNeasy Mini kit (cat. No. 74104, Qiagen) according to the manufacturer's instructions. DNA contamination was removed by treatment of samples with RNase-free DNase (Roche Diagnostics). RNA was dosed using Nano Drop ${ }^{\circledR}$ technology.

Total RNA (250 ng) was reverse transcribed in a total volume of $20 \mu \mathrm{l}$ with a First Strand cDNA Synthesis Kit (avian myeloblastosis virus reverse transcriptase, Roche Diagnostics) using oligo(dT)primers. Reverse transcription products were used for PCR using IQ Sybr Green Supermix (Bio Rad) according to the manufacturer's instructions in an iCycler (Bio Rad). After a denaturation step at $94^{\circ} \mathrm{C}$ for $9 \mathrm{~min}$, the samples were submitted to 45 cycles of $94^{\circ} \mathrm{C}$ for $15 \mathrm{~s}$, variable temperature depending on the primers for $15 \mathrm{~s}$ and $72^{\circ} \mathrm{C}$ for $45 \mathrm{~s}$. The sequences of the primers, the primer concentrations and their respective annealing temperatures are shown in table 1 . The PCR products were sequenced (Giga Sequencing, Belgium) using their respective primers. The results were expressed in $2^{-\Delta \mathrm{Ct}}(\mathrm{Ct}=$ cycle treshold). Classical PCR was performed with Go Taq polymerase (Promega) with the same conditions according to the manufacturer's instructions.

\section{Immunocytochemistry and Confocal Microscopy}

TNC and purified CD4+ T cells were layered on slides by sedimentation, then fixed with cold methanol for $7 \mathrm{~min}$ and cold methanol/acetone $(50: 50)$ for $3 \mathrm{~min}$. A permeation step with DPBS-Triton X-100 $(0.25 \%, \mathrm{w} / \mathrm{v})$ for $10 \mathrm{~min}$ at room temperature and a blockade step with DPBS-Triton X-100 (0.25\%, w/v) supplemented with $1 \%$ BSA (Sigma-Aldrich) and $10 \%$ normal goat serum (Jackson Immunoresearch Laboratories) were performed before antibody staining. Slides were incubated with rabbit polyclonal antimouse Foxp3 antibody $(10 \mu \mathrm{g} / \mathrm{ml}$; Abcam, ab10563) or rabbit polyclonal antimouse Aire antibody $(26.8 \mu \mathrm{g} / \mathrm{ml}$; kindly provided by Dr. Pärt Peterson) overnight at $4^{\circ} \mathrm{C}$. Subsequently, Alexa Fluor 488 -conjugated goat antirabbit antibody $(10 \mu \mathrm{g} / \mathrm{ml}$; Invitrogen) and Alexa Fluor 652-conjugated goat antirabbit antibody (10 $\mu \mathrm{g} / \mathrm{ml}$; Invitrogen), respectively, were applied for $2 \mathrm{~h}$ at room temperature. The slides were then washed (3 times) with DPBS and mounted in Dako Cytomation Fluorescent Mounting
Medium (Dako Cytomation). Nuclei were stained with Topro 3 (Invitrogen). All samples were observed with a Leica SP2 confocal microscope. Five-micrometer sections of whole thymus were made using a cryostat and stained with antimouse Aire and Foxp3 following the same methodology.

\section{Statistical Analysis}

For RT-qPCR, the mean value of duplicates was used. The results were expressed as the mean \pm SEM. A Mann-Whitney test was used for statistical analysis, and a $p$ value of $<0.05$ was chosen as the upper limit of statistical significance. All tests were performed using the Graph Pad Prism 4 software.

\section{Results}

\section{Foxp3 Expression}

Foxp3 expression was quantified by RT-qPCR (relative to $\beta$-actin), and the specificity of RT-PCR products was verified by sequencing. Freshly isolated thymocytes and TEC expressed Foxp3 at a high level, but its expression was very low in TEC cultured for 1 week (at a time when almost all thymocytes have disappeared; fig. 1). Isolated TNC/thymocyte complexes presented characteristic morphology when observed by phase contrast microscopy after staining with hematoxylin and eosin (data not shown). Foxp3 expression was also detected in TNC/thymocyte complexes, at a higher level than in cultured TEC, but the difference was not significant.

\section{Aire Expression}

Aire expression was detected by RT-PCR and RT-qPCR (for which the results were expressed relative to $\beta$-actin), and the specificity of RT-PCR products was also verified by sequencing. As shown after 35 or 40 cycles of semiquantitative PCR, TNC/thymocyte complexes and freshly isolated TEC expressed Aire (fig. 2A). Thymocytes presented much lower expression of Aire compared to TNC, 


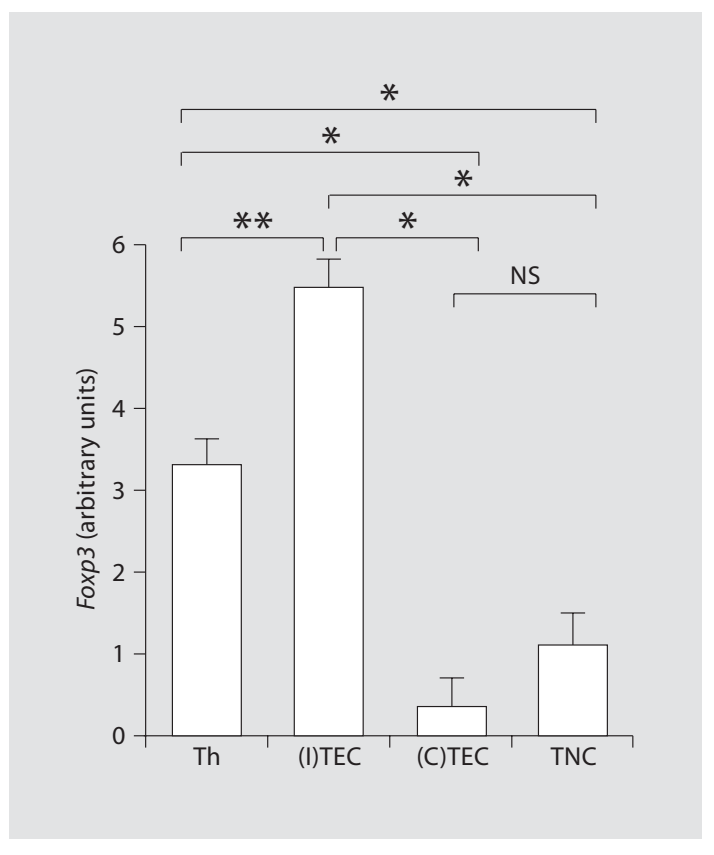

Fig. 1. Foxp3 expression was analyzed by RT-qPCR in thymocytes (Th; $\mathrm{n}=7$ ), freshly isolated TEC [(I)TEC; $\mathrm{n}=4]$, cultured TEC $[(\mathrm{C}) \mathrm{TEC} ; \mathrm{n}=5]$ and TNC/thymocyte complexes (TNC; $\mathrm{n}=3$ ). Values shown are means \pm SEM. ${ }^{*} \mathrm{p}<0.05 ;{ }^{* *} \mathrm{p}<0.01$. NS $=$ Not significant.

since expression was not detectable after 35 cycles. These observations were confirmed by RT-qPCR (fig. 2B). TNC/ thymocyte complexes expressed Aire at the same level as freshly isolated TEC, and Aire transcripts were significantly lower in thymocytes compared to freshly isolated TEC or TNC.

\section{Aire and Foxp3 Immunocytochemistry in Thymus \\ Sections and CD4+ Splenocytes}

As shown in figure $3 \mathrm{~B}$, Aire-positive cells were clearly identified in the medullary epithelium of murine thymus sections. No significant Aire staining appeared in the cortex or in the subcapsular region of the thymus. Foxp3positive cells were not only visualized in the medulla, but also in clusters of cell nuclei located in the subcapsular cortex (fig. 3C-E). Significant fractions of CD4+ T cell nuclei were also positive for Foxp3 and Aire antibodies (fig. 4E and $\mathrm{F}$, respectively).

\section{Aire and Foxp3 Localization in TNC/Thymocyte}

Complexes

Localization of Aire and Foxp3 in TNC/thymocyte complexes was performed by immunocytochemistry and
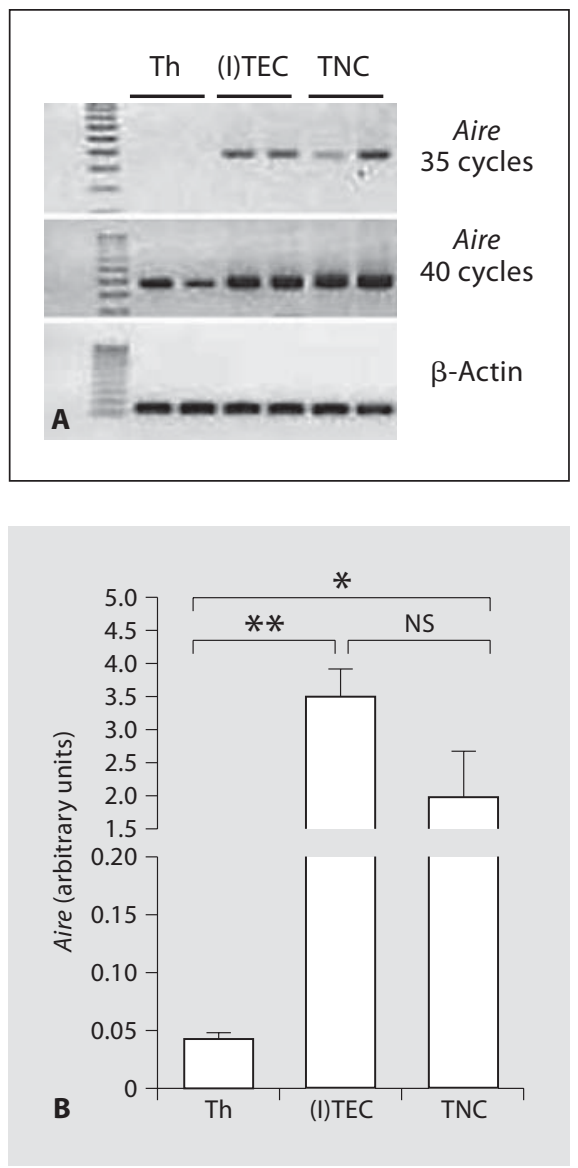

Fig. 2. Aire expression was analyzed by RT-PCR (A) and RT-qPCR (B) in thymocytes (Th; $\mathrm{n}=7)$, freshly isolated TEC [(I)TEC; $\mathrm{n}=$ 4] and TNC/thymocyte complexes (TNC; $\mathrm{n}=3$ ). Values shown are means \pm SEM. ${ }^{*} \mathrm{p}<0.05 ;{ }^{*} \mathrm{p}<0.01$. NS $=$ Not significant.

confocal microscopy. The negative control for the first and the second steps was staining with control immunoglobulin (Ig) or without primary antibody, respectively. Negative controls did not display any significant staining except for the Ig used for Foxp3 staining, which showed a slight halo around TNC complexes (fig. 5B).

Aire and Foxp3 were detected in TNC complexes, but not in the same compartments. Foxp3 was detected in the nucleus of thymocytes engulfed in TNC (fig. 5C, D). A few thymocytes outside the TNC complexes also expressed Foxp3. The staining observed around TNC complexes was the halo background also observed in the Ig negative control (fig. 5B). Aire was detected in the cytoplasm of TNC, but also in the nucleus of thymocytes inside and outside the complexes (fig. 6C, D). 

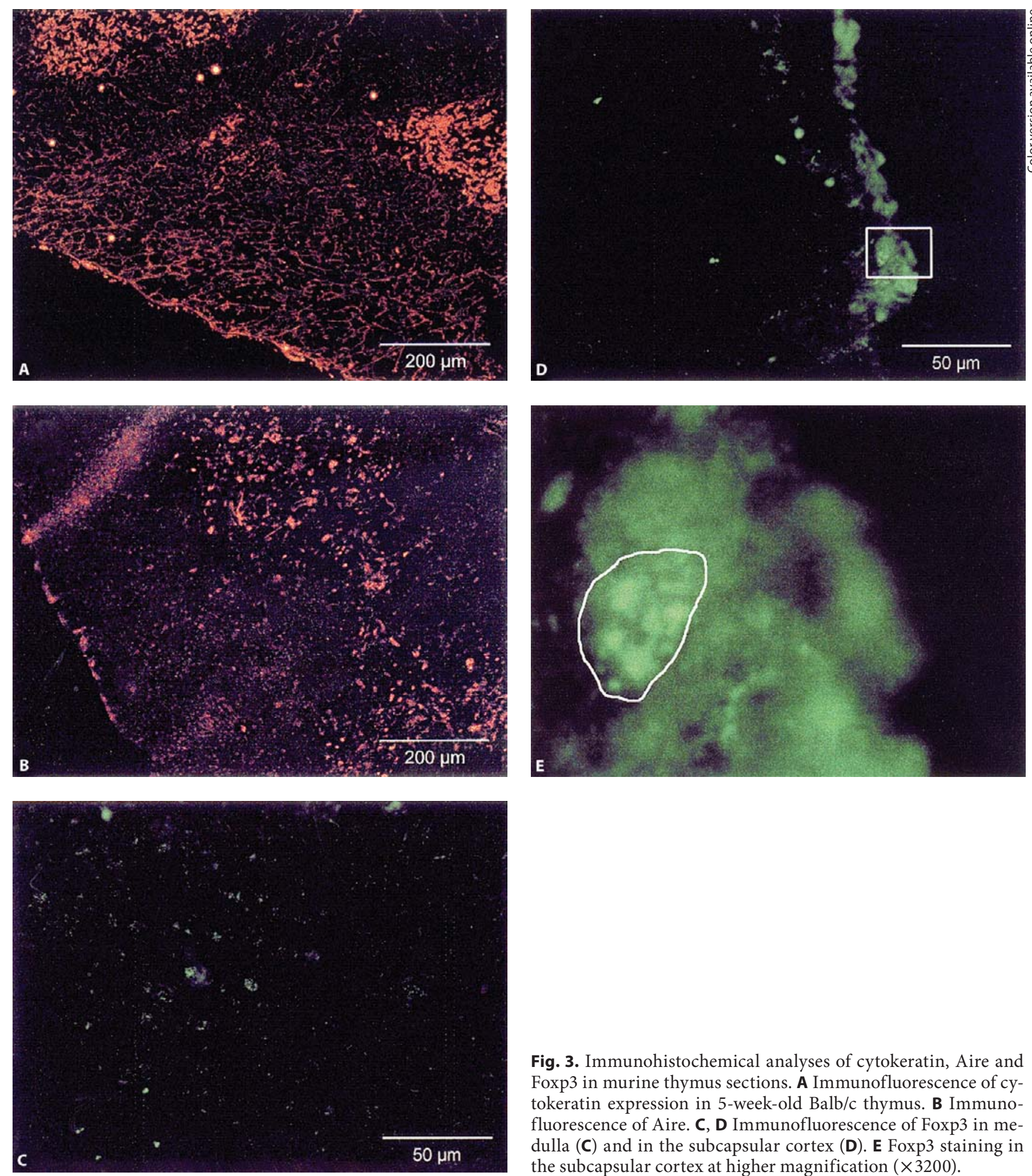

Fig. 3. Immunohistochemical analyses of cytokeratin, Aire and Foxp3 in murine thymus sections. A Immunofluorescence of cytokeratin expression in 5-week-old Balb/c thymus. B Immunofluorescence of Aire. C, D Immunofluorescence of Foxp3 in medulla (C) and in the subcapsular cortex (D). E Foxp3 staining in the subcapsular cortex at higher magnification $(\times 3200)$. 


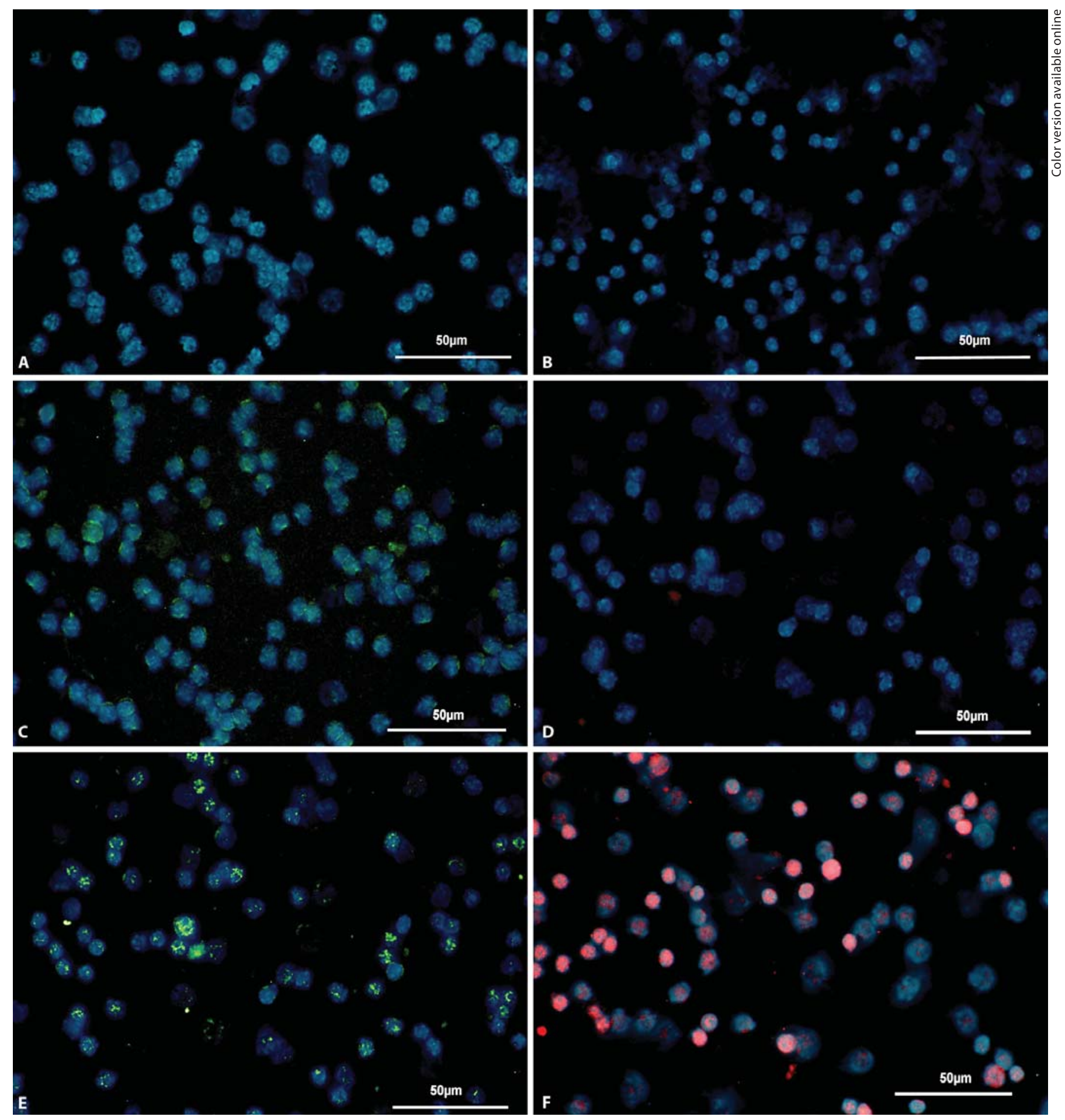

Fig. 4. Foxp3 (A, C, E) and Aire (B, D, F) immunostaining in isolated CD4+ splenocytes. A, B Negative controls (DPBS buffer-Triton X-100). C, D Staining with control Ig as first antibody. E, F Staining with anti-Foxp3 (E) and anti-Aire (F). 
Fig. 5. Localization of Foxp3 in TNC/thymocyte complexes by immunocytochemistry and confocal microscopy. Negative controls were performed without primary antibody (A) or with control Ig (B). AntiFoxp3 antibody reveals Foxp3 localization in the nucleus of thymocytes inside and outside TNC/thymocyte complexes (C, D).
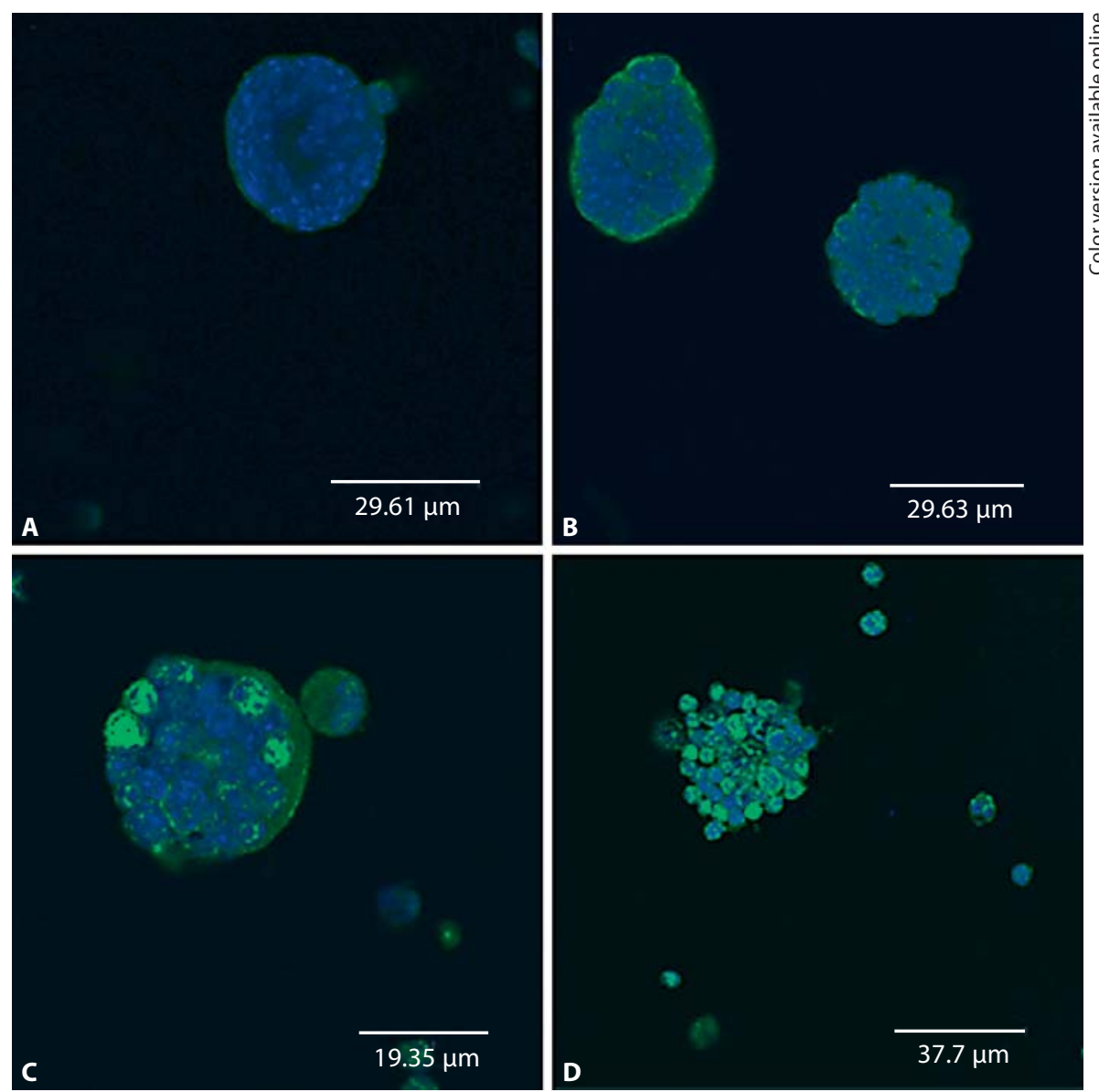

\section{Discussion}

The principal objective of this study was to investigate the expression and localization of Aire and Foxp3 in a particular microenvironment of the thymus, i.e. the complexes constituted by TNC and internalized thymocytes. Foxp3 expression was clearly detected in thymocytes, as well as in freshly isolated TEC. Since Foxp3 expression disappeared in cultured TEC after 1 week, at a time when thymocytes have almost completely disappeared, Foxp3 expression in fresh TEC was most probably due to contaminating thymocytes. Foxp3 expression was also clearly identified in TNC/thymocyte complexes. With immunocytochemistry, Foxp3 expression was found in the nuclei of $\mathrm{T}$ cells in thymic medulla, but also in clusters of nuclei located in the subcapsular cortex, which could correspond to in situ TNC/thymocyte complexes. In TNC/ thymocyte complexes, Foxp3 expression was restricted to thymocytes in and out of the complexes. Aire expression was found by 35-cycle RT-PCR and RT-qPCR in fresh
TEC and in isolated TNC/thymocyte complexes. Aire expression was also detected by 40 -cycle RT-PCR within thymocytes; however, Aire expression in thymocytes was very low compared to that in freshly isolated TEC and TNC/thymocyte complexes. Therefore, Aire expression predominated in TEC and the epithelial compartment of TNC, although a low level of expression was sufficient for positive immunostaining as shown in isolated CD4+ T cells and in nuclei of TNC/thymocyte complexes.

The existence of TNC/thymocyte complexes has been discussed for a long time [for a review, see 16]. Some investigators consider these complexes to be an artifact resulting from the isolation procedure leading to internalization of thymocytes into a 'classical' TEC $[28,29]$. However, TEC and TNC cell lines have been shown to be able to internalize thymocytes in vitro [20]. In addition, TNC complexes have been observed in situ in the thymic outer cortex using the TNC-specific antibody ph91 [30].

TNC are included among the thymic reticuloepithelial cells that express many neuroendocrine factors [22]. 
Fig. 6. Localization of Aire in TNC/thymocyte complexes by immunocytochemistry and confocal microscopy. Negative controls were performed without primary antibody (A) or with control Ig (B). AntiAire antibody reveals Aire localization in TNC cytoplasm and also in the nucleus of thymocytes inside and outside TNC/thymocyte complexes (C, D).
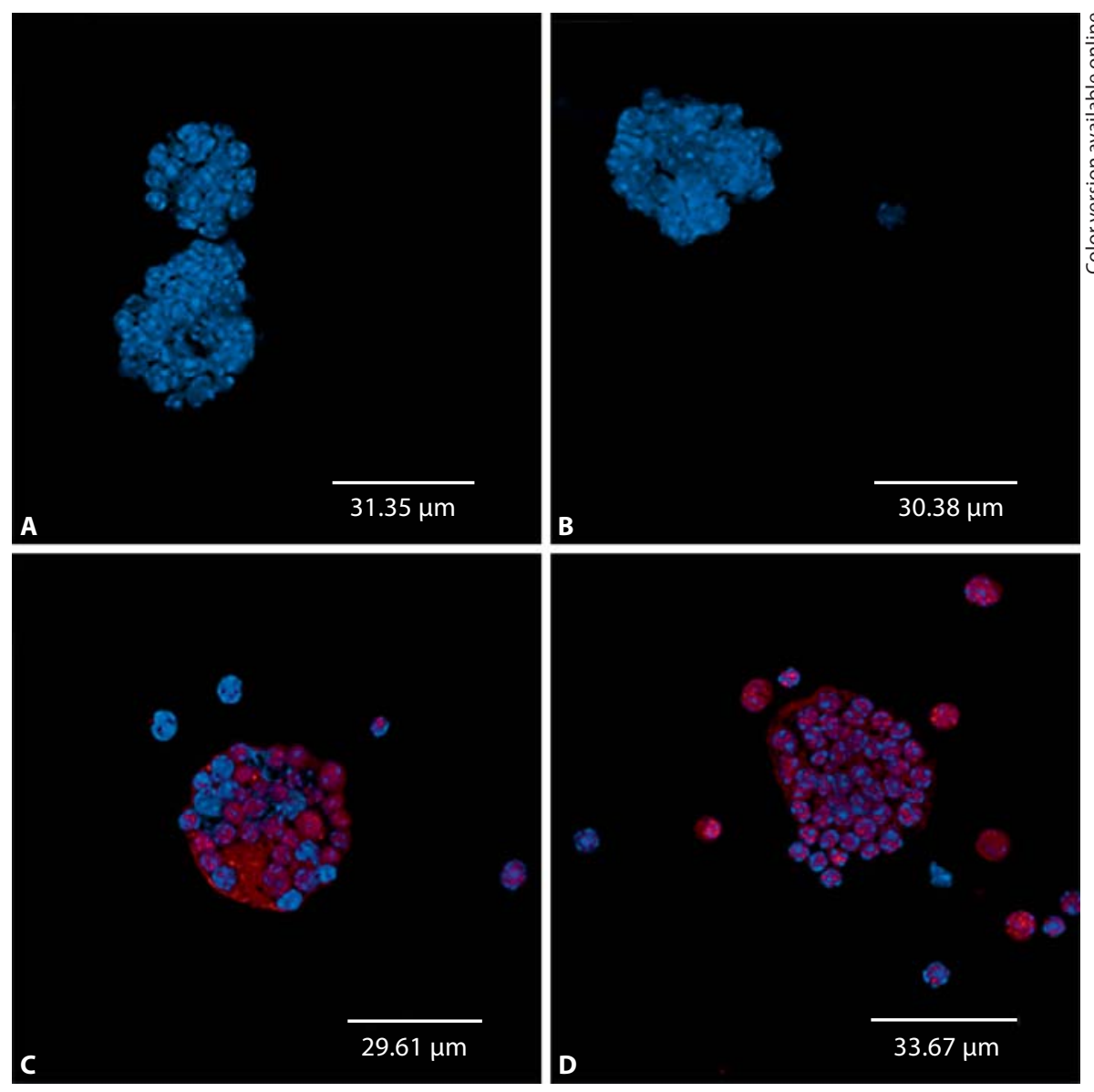

T cell development has been shown to be finely regulated by neuropeptides [9] belonging to different families such as the neurohypophysial family (OT and vasopressin) [31, 32] or the insulin family (IGF-1, IGF-2 and insulin) [33]. The intrathymic expression of genes encoding OT, IGF-2 and insulin is regulated by Aire [11]. In light of previous studies on the location of Aire in the thymus, we considered it unlikely for Aire to be expressed in TNC, since Aire expression has mainly been described in medullary TEC, while cortical TEC apparently do not display any Aire expression [34-37]. The same spatial expression of Aire was observed in the present study. Nevertheless, an interesting observation from this study was the identification of Foxp3-positive nuclei clusters in the subcapsular cortex. Such formations could in fact correspond to in situ TNC/thymocyte complexes, despite the fact that Aire immunostaining was negative in the outer and subcapsular cortex. Thus, isolated Aire-positive TNC could represent either medulla-derived TNC or an association between medullary TEC and thymocytes.
Some analogies were previously observed between the medulla and subcortical area in the thymus. Staining of thymic sections with A2B5 monoclonal antibody and tetanus toxin (both bind different subtypes of gangliosides) distinguished the positive medulla and subcapsular region from the other zones of the thymus [38]. Interestingly, TNC have been shown to be identified by A2B5 expression [22].

Another debate concerns the respective roles of the thymic medulla and cortex in the selection of nTreg. Medullary TEC are considered to be very efficient in nTreg development as shown in a recent study [39]. However, there is also experimental evidence showing that cortical TEC are also involved in nTreg selection [40, 41].

In our study, Aire was located in the cytoplasm of TNC, indicating that this protein could be associated with microtubules [42]. Even if some thymocytes inside and outside TNC complexes express Aire, this expression as quantified by RT-qPCR is very low compared to freshly isolated TEC and TNC complexes. In addition to TNC- 
engulfed thymocytes, Aire expression was also detected in CD4+ splenocytes, which is in agreement with some previously reported observations [43-45]. Cultures of freshly isolated TNC could enable the separation of thymocytes from TNC, and thus facilitate characterization of Aire expression. However, in two-dimension cultures, Aire expression is lost as observed in culture of TEC [46; pers. observations].

Another interesting observation was Foxp3 expression by many $\mathrm{T}$ cells inside TNC/thymocyte complexes. Since it is very unlikely that all these Foxp3-positive cells will differentiate into nTreg, this expression may in fact precede further intrathymic selection of nTreg. Alternatively, Foxp3 expression in many TNC-engulfed thymocytes may be related to some degree of $\mathrm{T}$ cell activation in this microenvironment, as T cell activation is known to be a key event in Foxp3 expression [47].

In summary, the differential expression of Aire in TNC and of Foxp3 in TNC-associated thymocytes supports the idea of a close interaction between these factors in the process of nTreg development and suggests that TNC may also be implicated in nTreg selection.

\section{Acknowledgements}

This work was supported by the Fund of Scientific Research, Belgium, the European Union (FP6 Integrated Project Euro-Thymaide LSHB-CT-2003-503410) and the DGTRE/Walloon Region (project Waleo 2 Tolediab).

\section{References}

1 Sakaguchi S: Naturally arising CD4+ regulatory $\mathrm{T}$ cells for immunologic self-tolerance and negative control of immune responses. Annu Rev Immunol 2004;22:531-562.

-2 Sakaguchi S, Ono M, Setoguchi R, Yagi H, Hori S, Fehervari Z, Shimizu J, Takahashi T, Nomura T: Foxp3+ CD25+ CD4+ natural regulatory $\mathrm{T}$ cells in dominant self-tolerance and autoimmune disease. Immunol Rev 2006;212:8-27.

3 Derbinski J, Schulte A, Kyewski B, Klein L: Promiscuous gene expression in medullary thymic epithelial cells mirrors the peripheral self. Nat Immunol 2001;2:1032-1039.

-4 Derbinski J, Gabler J, Brors B, Tierling S, Jonnakuty S, Hergenhahn M, Peltonen L, Walter J, Kyewski B: Promiscuous gene expression in thymic epithelial cells is regulated at multiple levels. J Exp Med 2005;202:33-45.

5 Markwick AJ, Lolait SJ, Funder JW: Immunoreactive arginine vasopressin in the rat thymus. Endocrinology 1986;119:16901696.

-6 Geenen V, Legros JJ, Franchimont P, Baudrihaye M, Defresne MP, Boniver J: The neuroendocrine thymus: coexistence of oxytocin and neurophysin in the human thymus. Science 1986;232:508-511.

$\checkmark 7$ Geenen V, Achour I, Robert F, Vandersmissen E, Sodoyez JC, Defresne MP, Boniver J, Lefebvre PJ, Franchimont P: Evidence that insulin-like growth factor 2 (IGF2) is the dominant thymic peptide of the insulin superfamily. Thymus 1993;21:115-127.

$\checkmark 8$ Kecha O, Martens H, Franchimont N, Achour I, Hazee-Hagelstein MT, CharletRenard C, Geenen V, Winkler R: Characterization of the insulin-like growth factor axis in the human thymus. J Neuroendocrinol 1999;11:435-440.
-9 Hansenne I: Thymic transcription of neurohypophysial and insulin-related genes: impact upon T-cell differentiation and self-tolerance. J Neuroendocrinol 2005; 17:321-327.

10 Mathis D, Benoist C: A decade of AIRE. Nat Rev Immunol 2007;7:645-650.

11 Anderson MS, Venanzi ES, Klein L, Chen Z, Berzins SP, Turley SJ, von Boehmer H, Bronson R, Dierich A, Benoist C, Mathis D: Projection of an immunological self shadow within the thymus by the aire protein. Science 2002;298:1395-1401.

12 Ramsey C, Winqvist O, Puhakka L, Halonen M, Moro A, Kampe O, Eskelin P, PeltoHuikko M, Peltonen L: Aire deficient mice develop multiple features of APECED phenotype and show altered immune response. Hum Mol Genet 2002;11:397-409.

13 Peterson P, Peltonen L: Autoimmune polyendocrinopathy syndrome type 1 (APS1) and AIRE gene: new views on molecular basis of autoimmunity. J Autoimmun 2005;25 (suppl):49-55.

14 Taubert R, Schwendemann J, Kyewski B: Highly variable expression of tissue-restricted self-antigens in human thymus: implications for self-tolerance and autoimmunity. Eur J Immunol 2007;37:838-848.

-15 Pezzano M, Samms M, Martinez M, Guyden J: Questionable thymic nurse cell. Microbiol Mol Biol Rev 2001;65:390-403.

$\checkmark 16$ Guyden JC, Pezzano M: Thymic nurse cells: a microenvironment for thymocyte development and selection. Int Rev Cytol 2003;223: 1-37.

17 Wekerle H, Ketelsen UP, Ernst M: Thymic nurse cells. Lymphoepithelial cell complexes in murine thymuses: morphological and serological characterization. J Exp Med 1980; 151:925-944.
18 Defresne MP, Goffinet G, Boniver J: In situ characterization in freeze-fractured mouse thymuses of lymphoepithelial complexes ultrastructurally similar to isolated thymic nurse cells. Tissue Cell 1986;18:321-330.

19 Toussaint-Demylle D, Scheiff JM, Haumont S: Thymic accessory cell complexes in vitro and in vivo: morphological study. Cell Tissue Res 1991;263:293-301.

20 Philp D, Pezzano M, Li Y, Omene C, Boto W, Guyden J: The binding, internalization, and release of thymocytes by thymic nurse cells. Cell Immunol 1993;148:301-315.

21 Webb O, Kelly F, Benitez J, Li J, Parker M, Martinez M, Samms M, Blake A, Pezzano M, Guyden JC: The identification of thymic nurse cells in vivo and the role of cytoskeletal proteins in thymocyte internalization. Cell Immunol 2004;228:119-129.

22 Geenen V, Defresne MP, Robert F, Legros JJ, Franchimont P, Boniver J: The neurohormonal thymic microenvironment: immunocytochemical evidence that thymic nurse cells are neuroendocrine cells. Neuroendocrinology 1988;47:365-368.

23 Gavin MA, Rasmussen JP, Fontenot JD, Vasta V, Manganiello VC, Beavo JA, Rudensky AY: Foxp3-dependent programme of regulatory T-cell differentiation. Nature 2007;445: 771-775.

24 Lin W, Haribhai D, Relland LM, Truong N, Carlson MR, Williams CB, Chatila TA: Regulatory $\mathrm{T}$ cell development in the absence of functional Foxp3. Nat Immunol 2007;8:359368.

25 Nomura T, Sakaguchi S: Foxp3 and Aire in thymus-generated Treg cells: a link in selftolerance. Nat Immunol 2007;8:333-334. 
26 Houben-Defresne MP, Varlet A, Goffinet G, Boniver J: Thymic nurse cells are the first site of virus replication after inoculation of the radiation leukemia virus. Leuk Res 1982;6: 231-241.

-27 Brilot F, Chehadeh W, Charlet-Renard C, Martens H, Geenen V, Hober D: Persistent infection of human thymic epithelial cells by coxsackievirus B4. J Virol 2002;76:52605265.

-28 Kyewski BA, Kaplan HS: Lymphoepithelial interactions in the mouse thymus: phenotypic and kinetic studies on thymic nurse cells. J Immunol 1982;128:2287-2294.

-29 Toussaint-Demylle D, Scheiff JM, Haumont S: Thymic nurse cells: morphological study during their isolation from murine thymus. Cell Tissue Res 1990;261:115-123.

>30 Pezzano M, King KD, Philp DD, Adeyemi A, Gardiner B, Yang J, Samms M, Boto W, Guyden JC: A thymic nurse cell-specific monoclonal antibody. Cell Immunol 1998; 185:123-133.

-31 Hansenne I, Rasier G, Pequeux C, Brilot F, Renard C, Breton C, Greimers R, Legros JJ, Geenen V, Martens HJ: Ontogenesis and functional aspects of oxytocin and vasopressin gene expression in the thymus network. J Neuroimmunol 2005;158:67-75.

-32 Hansenne I, Rasier G, Charlet-Renard C, DeFresne MP, Greimers R, Breton C, Legros JJ, Geenen V, Martens H: Neurohypophysial receptor gene expression by thymic T cell subsets and thymic $\mathrm{T}$ cell lymphoma cell lines. Clin Dev Immunol 2004;11:45-51.

-33 Kecha O, Brilot F, Martens H, Franchimont N, Renard C, Greimers R, Defresne MP, Winkler R, Geenen V: Involvement of insulin-like growth factors in early T cell development: a study using fetal thymic organ cultures. Endocrinology 2000;141:12091217.
>34 Heino M, Peterson P, Sillanpaa N, Guerin S, Wu L, Anderson G, Scott HS, Antonarakis SE, Kudoh J, Shimizu N, et al: RNA and protein expression of the murine autoimmune regulator gene (Aire) in normal, RelB-deficient and in NOD mouse. Eur J Immunol 2000;30:1884-1893.

35 Zuklys S, Balciunaite G, Agarwal A, FaslerKan E, Palmer E, Hollander GA: Norma thymic architecture and negative selection are associated with Aire expression, the gene defective in the autoimmune-polyendocrinopathy-candidiasis-ectodermal dystrophy (APECED). J Immunol 2000;165:19761983.

36 Halonen M, Pelto-Huikko M, Eskelin P, Peltonen L, Ulmanen I, Kolmer M: Subcellular location and expression pattern of autoimmune regulator (Aire), the mouse orthologue for human gene defective in autoimmune polyendocrinopathy candidiasis ectodermal dystrophy (APECED). J Histochem Cytochem 2001;49:197-208.

37 Kont V, Laan M, Kisand K, Merits A, Scott HS, Peterson P: Modulation of Aire regulates the expression of tissue-restricted antigens. Mol Immunol 2008;45:25-33.

38 Haynes BF, Shimizu K, Eisenbarth GS: Identification of human and rodent thymic epithelium using tetanus toxin and monoclonal antibody A2B5. J Clin Invest 1983;71:9-14.

39 Aschenbrenner K, D’Cruz LM, Vollmann EH, Hinterberger M, Emmerich J, Swee LK, Rolink A, Klein L: Selection of Foxp3+ regulatory $\mathrm{T}$ cells specific for self antigen expressed and presented by Aire+ medullary thymic epithelial cells. Nat Immunol 2007;8: 351-358.

40 Bensinger SJ, Bandeira A, Jordan MS, Caton AJ, Laufer TM: Major histocompatibility complex class II-positive cortical epithelium mediates the selection of CD4(+)25(+) immunoregulatory T cells. J Exp Med 2001;194: 427-438.
41 Ribot J, Enault G, Pilipenko S, Huchenq A, Calise M, Hudrisier D, Romagnoli P, van Meerwijk JP: Shaping of the autoreactive regulatory $\mathrm{T}$ cell repertoire by thymic cortical positive selection. J Immunol 2007;179: 6741-6748.

-42 Pitkanen J, Vahamurto P, Krohn K, Peterson P: Subcellular localization of the autoimmune regulator protein. Characterization of nuclear targeting and transcriptional activation domain. J Biol Chem 2001;276:1959719602.

43 Rinderle C, Christensen HM, Schweiger S, Lehrach H, Yaspo ML: AIRE encodes a nuclear protein co-localizing with cytoskeletal filaments: altered sub-cellular distribution of mutants lacking the PHD zinc fingers. Hum Mol Genet 1999;8:277-290.

44 Adamson KA, Pearce SH, Lamb JR, Seckl JR, Howie SE: A comparative study of mRNA and protein expression of the autoimmune regulator gene (Aire) in embryonic and adult murine tissues. J Pathol 2004;202:180-187.

45 Nagafuchi S, Katsuta H, Koyanagi-Katsuta R, Yamasaki S, Inoue Y, Shimoda K, Ikeda Y, Shindo M, Yoshida E, Matsuo T, et al: Autoimmune regulator (AIRE) gene is expressed in human activated CD4+ T-cells and regulated by mitogen-activated protein kinase pathway. Microbiol Immunol 2006;50:979987.

46 Palumbo MO, Levi D, Chentoufi AA, Polychronakos $\mathrm{C}$ : Isolation and characterization of proinsulin-producing medullary thymic epithelial cell clones. Diabetes 2006;55: 2595-2601.

$\checkmark 47$ Allan SE, Crome SQ, Crellin NK, Passerini L, Steiner TS, Bacchetta R, Roncarolo MG, Levings ML: Activation-induced FOXP3 in human $\mathrm{T}$ effector cells does not suppress proliferation or cytokine production. Int Immunol 2007;19:345-354. 